\title{
VERDADE ARTÍSTICA E RESISTÊNCIA POLÍTICA EM KAFKA E QUEERMUSEU
}

\author{
ARTISTIC TRUTH AND POLITICAL RESISTANCE IN KAFKA AND THE \\ QUEERMUSEUM
}

Recebido: 13/01/2021

Aprovado: $17 / 05 / 2021$

Publicado: $30 / 07 / 2021$

DOI: $10.18817 /$ rlj.v5i01.2587

Luciana Barreto Machado Rezende ${ }^{1}$ https://orcid.org/0000-0002-2416-2085

O artista é a força incontrolável: depois de Van Gogh, nenhum olhar ocidental pode contemplar um cipreste sem notar nele o princípio de uma chama.

George Steiner

\begin{abstract}
Resumo: No atual contexto de avanço das forças conservadoras e da progressiva degradação das bases democráticas que assentam o Estado brasileiro, faz-se procedente a releitura crítica de "O artista da fome", conto da última produção de Franz Kafka $(1883$ - 1924), bem como do ensaio "O direito à literatura", texto seminal de Antonio Candido. Ao compreendermos o ofício do jejuador como uma alegoria do fazer artístico e da verdade do artista, o qual não sucumbe à indústria da cultura e do entretenimento, a resistência assumida por esse "artista da fome" ilustra a angústia que acomete o homem moderno, imerso nas contradições entre o progresso tecnológico e a exclusão social. Tal situação narrativa se alinha ainda ao episódio de censura à exposição "Queermuseu - Cartografia da Diferença na América Latina", em função de ataques de grupos religiosos e conservadores, encerrada pelo Santander Cultural em 2017, na cidade gaúcha de Porto Alegre. Além de abordarmos as inovações formais - na narrativa kafkiana na expressão pictural da tela "Cruzando Jesus com o Deus Shiva", de Fernando Baril, da referida mostra -, mostramos como a arte e a literatura configuram poderosos e humanizadores instrumentos de educação e instrução, além de apreensão crítica da realidade e engajamento político.
\end{abstract}

Palavras-chave: Franz Kafka. Queermuseu. Antonio Candido. Arte. Resistência.

Abstract:In the current context of rapid advance of the conservative forces and the progressive deterioration of the democratic bases that underlie the Brazilian State, it is of the utmost importance to revisit two major works. They are the critical reinterpretation of "The artist of hunger", a story from the last composing era of Franz Kafka (1883 - 1924), and the essay "The right to literature", seminal text by Antonio Candido. When we understand the craft of fasting as an allegory of artistic making and from the artist's truth, who does not succumb to the culture and entertainment industry, the resistance assumed by this "starving artist" illustrates the anguish that affects the modern man, immersed in the contradictions between technological progress and social exclusion. Such narrative is also in line with the episode of censorship of the exhibition "Queermuseu - Cartography of Difference in Latin America", due to attacks by religious and conservative groups, shut down by Santander Cultural in 2017, in Porto Alegre, Rio Grande do Sul. In addition to addressing the formal innovations - in the Kafkaesque narrative in the pictorial expression of the painting "Cruzando Jesus com o Deus Shiva", by Fernando Baril, from the afore mentioned exhibition -, we show how art and literature set up powerful and humanizing instruments of education and instruction, in addition to the critical apprehension of reality and political engagement.

Keywords: Franz Kafka. Queermuseum. Antonio Candido. Art. Resistance.

\footnotetext{
1 Doutorou-se, em 2017, em Literatura e Práticas Sociais pela Universidade de Brasília, com a tese A Poética da Queda em Avalovara em diálogo com A Divina Comédia. Mestrado em Teoria Literária (2008) e Graduação em Comunicação (1992), pela mesma instituição. Estuda os universos de Osman Lins, Hilda Hilst, Clarice Lispector e Fernando Pessoa. Atuou, de 2018 a 2020, como professora de Literaturas Portuguesa e Brasileira na UnB. Integra os Grupos de Pesquisa do CNPq: 'Estudos Osmanianos: arquivo, obra, campo literário' e 'Literatura e Cultura'. E-mail: lubarretinha@gmail.com
} 


\section{Introdução}

De caráter assertivo, resistência é um conceito que advém da ética, não da estética. Mas são justamente os valores da resistência que despertam a mirada crítica do artista. Deriva do latim resistentia, de resistere, "ficar firme, aguentar", formado por re ("para trás, contra") mais sistere ("ficar firme, manter a posição"), interpondo, assim, a força própria à investida alheia. Alfredo Bosi nos lembra ainda que "o cognato próprio é in/sistir; o antônimo familiar é de/sistir" (BOSI, 2002, p. 118). Para o crítico, nas aproximações entre narrativa e resistência, "há momentos coletivos em que o élan revolucionário polariza e comove tanto os homens de ação como os criadores de ficção" (p. 125). E prossegue: "[...] o artista da palavra pode desenvolver, solitária e independentemente, a sua resistência aos antivalores do meio. Será o "coração do mundo' do poeta" (p. 125).

Nesse sentido, no atual contexto de avanço das forças conservadoras e da progressiva degradação das bases democráticas que assentam o Estado brasileiro, faz-se procedente a releitura crítica de "O artista da fome", conto da última produção de Franz Kafka (1883 - 1924), que transmuta a própria condição judaica de estrangeiridade e não pertencimento, de terror político vivenciado pelo escritor durante a $1^{\text {a }}$ Guerra Mundial ante a ascensão do nazismo, bem como do ensaio "O direito à literatura", texto seminal de Antonio Candido, datado de 1988 e publicado em um volume dedicado à questão dos direitos humanos.

Ao compreendermos o ofício do jejuador kafkiano como uma alegoria do fazer artístico e da verdade indeclinável do artista, o qual não sucumbe à indústria da cultura e do entretenimento, a resistência assumida por esse "artista da fome" ilustra a angústia que acomete o homem moderno, imerso nas contradições entre o progresso tecnológico e a exclusão social. Tal situação narrativa se alinha ainda ao recente episódio de censura à exposição Queermuseu - Cartografia da Diferença na América Latina, em função de ataques homofóbicos de pessoas da sociedade, grupos religiosos e partidos políticos, encerrada pelo banco Santander Cultural no dia 10 de setembro de 2017, na cidade de Porto Alegre, Rio Grande do Sul.

Além de abordarmos os aspectos relacionados às inovações formais - seja na narrativa kafkiana, seja na expressão pictural especialmente da tela intitulada Cruzando Jesus com o Deus Shiva, de Fernando Baril, da referida mostra -, demarcamos como a arte e a literatura configuram poderosos e humanizadores 
instrumentos de educação e instrução, além de subsequentes apreensão crítica da realidade e engajamento político, capazes, como aponta o professor Candido, do esperado desenvolvimento da "cota de humanidade na medida em que nos torna mais compreensivos e abertos para a natureza, a sociedade, o semelhante" (CANDIDO, 1988/2011, p. 182).

Impossível mencionarmos Kafka sem associar o seu universo literário a absolutos desconcerto e estranheza. Reconhecemo-nos nessa atmosfera de isolamento, incomunicabilidade e não pertencimento, nesse ser-estar convulsivo e em constante desalinho. Sabidamente, o termo "kafkiano" passou a ser assumido como adjetivo - sinônimo de alienação, perseguição, situações absurdas e asfixiantes.

Justamente por isso escolhi uma narrativa de Kafka para tentar ilustrar a situação absurda e descabida que estamos vivendo no Brasil, do que venho chamando de "realidade insólita", cuja narrativa política vem-se desenhando desde 2016, em uma daquelas urdidas (e engenhosas) tramas: uma presidenta honesta e democraticamente eleita deposta e publicamente tripudiada, inclusive pelo candidato que hoje ocupa, graças a uma campanha massiva de fake news, a cadeira da presidência da República (e que aproveitou o momento do seu voto no processo de impeachment para, em um gesto hediondo e abominável, homenagear o chefe da tortura no país); um ex-chefe de Estado, de expressão internacional e $1^{\circ}$ lugar nas intenções de votos, preso em um processo judicial sumário e politicamente manipulado mesmo sem a comprovação dos supostos crimes de corrupção (enfim, agora absolvido após 580 dias detido na sede da Superintendência da Polícia Federal do Paraná, em Curitiba); a supressão programada e continuada de direitos historicamente conquistados; determinadas negligências pelos Três Poderes da República a clamores da sociedade civil, a despeito mesmo das necessidades mais legítimas e urgentes; a execução violenta da vereadora fluminense Marielle Franco, e de seu motorista Anderson Gomes, por sua defesa irrestrita de LGBTI, de direitos humanos e pessoas socialmente vulneráveis, bem como as denúncias sugerindo o envolvimento de policiais com traficantes e milícias paramilitares; as forças conservadoras de ultradireita propagando e encampando discursos de ódio contra negros, pobres, mulheres, comunistas e gays, os quais já vêm-se revertendo em lastimáveis e continuadas cenas de violências concretas e simbólicas. 


\section{Kafka e a alegoria do fazer artístico}

Franz Kafka, nascido em Praga, antiga Tchecoslováquia, em 1883, morreu precocemente em 1924, aos 41 anos de idade, de tuberculose na laringe. Sem dúvida, um dos maiores nomes da literatura de língua alemã, a ponto de ter influenciado escritores como Becket, Camus e Sartre. Cabe dispormos aqui um fato curioso: consta que, no leito de morte, em um sanatório perto de Viena, por conta de sua condição gravíssima de saúde, não conseguia mais se alimentar. E é nesse exato momento que ele compõe o conto "Um artista da fome". Não é difícil depreendermos como o escritor extrai um dado da sua própria (e terrível) realidade para operar o salto ficcional e compor a própria alegoria do fazer artístico, da expressão da vontade, da verdade indeclinável que deve mover o sujeito. Como analisa Modesto Carone, importante tradutor e especialista em sua obra, no posfácio à coletânea publicada, em Berlim, pelo próprio Kafka entre 1923 e 1924, cujas narrativas integram à produção final do escritor:

Cabe acrescentar que todos esses contos foram concebidos ou elaborados quando o escritor estava morando em Berlim, entre o fim de 1923 e o início de 1924. Nessa época a tuberculose que devia matá-lo já alcançava a laringe e o nacional-socialismo mostrava as garras, o que sem dúvida repercutia, seja em "Um artista da fome", que transfigura a impossibilidade física que Kafka tinha para engolir, seja no conto da "mulherzinha", cujo ódio ao narrador é tão implacável e destrutivo como o rancor sem limites dos nazistas aos judeus. Nesse contexto, não é excesso de imaginação achar que as ansiedades do povo dos camundongos espelhem as angústias do escritor nos tempos sombrios da ascensão do nazismo (CARONE, 1998, p. 73).

E no leito ficcional de Kafka, alguns elementos são recorrentes (e assim configuram o seu imaginário literário): as suas narrativas têm um quê de labirínticas, sendo "circulares pela repetição das mesmas situações fundamentais" (ROSENFELD, 1999, p.30), como sublinha Anatol Rosenfeld. Em seu mundo ficcional, assumem vulto a questão burocrática e a condenação injusta em O Processo; a história do agrimensor $\mathrm{K}$, que não consegue entrar em O Castelo; o horror experienciado por Gregor Samsa, o qual se transforma em uma barata, pois declina de seus próprios desejos, para sustentar a família.

Em seu procedimento de desfabulação, isto é, de trazer enredos rarefeitos cuja narração não deriva de histórias lineares ancoradas em relações de causa-efeito, Kafka contribuiu significativamente para a desestabilização do gênero romanesco. Em 
O Processo e O Castelo, por exemplo, Kafka deixa de inventar nomes (limitando-se a 'K'). Em “Um artista da fome”, os personagens são apresentados como 'jejuador', 'inspetor', 'moça'. A falta de nomes próprios indica uma despersonalização proposital de seus entes ficcionais, o destino das figuras anônimas, como analisa Rosenfeld (1999). Indubitavelmente, os seus peculiares heróis são, portanto, anti-heróis.

E para assinalar esse eu imerso e atônito no turbilhão humano, outra estratégia se faz essencial em sua narração: o antipsicologismo, já que os seus personagens não se configuram exatamente como indivíduos, mas como consciências atormentadas, como processos psíquicos extenuados - e o próprio sujeito ora fragmentado e aniquilado pelas forças gigantescas de uma sociedade opressora, ou desesperadamente tentando manter-se íntegro e coerente, a despeito do estranho mundo que lhe circunda.

A dicção estilística de Kafka é recorrentemente fria, sóbria, cortante, a partir da qual deslinda sempre experiências terrificantes. Devemos chamar atenção ainda a naturalidade com que narra a desumanidade, a monstruosidade flagrada no mundo e entre as pessoas - afinal o desumano deve ser exposto a seco.

Em "Um artista da fome", escrito em 1922 e publicado dois anos depois, Kafka nos apresenta um jejuador que outrora - e gloriosamente - foi uma grande atração pública: "Antigamente, toda a cidade se ocupava com os artistas da fome" (KAFKA, 1922/1998, p. 14). O interesse coletivo progredia com o passar dos dias e todos queriam assistir àquele homem, que resistia, com orgulho e altivez, à fome, recusando qualquer alimento.

Vigilantes escolhidos pelo público acompanhavam dia e noite o jejuador, para assegurar que ele não se alimentasse ocultamente. E isso o atormentava: "[...] às vezes, superando a fraqueza, ele cantava, enquanto tinha forças, no período de vigia, para mostrar as pessoas como era injusto suspeitarem dele". O artista, de fato, "jejuava como nenhum deles seria capaz" (KAFKA, 1922/1998, p. 16). Ainda, sim, estranhamente, era muito fácil para ele jejuar. "Ele não o ocultava, mas não acreditavam nele; no melhor dos casos consideravam-no modesto" (p. 17).

O período máximo em que permanecia jejuando era de quarenta dias - prazo fixado pelo empresário, durante o qual podiam transcorrer o assédio e o interesse pelo artista. Mas o desjejum era para ele sempre incômodo, desagradável, não somente 
pelas náuseas que sentia apenas em pensar no que comeria, como também porque simplesmente o impediam de continuar jejuando. "Ele poderia aguentar ainda muito tempo, um tempo ilimitado; por que suspender agora quando estava no melhor, isto é, ainda não estava no melhor do jejum?" (KAFKA, 1922/1998, p. 17).

E o que significa isso? Esse tempo desafiador a ser suportado em seu ofício? Diante da contingência do desjejum, bem como das tentações interpostas pelos espectadores, o próprio narrador responde: "A honra da sua arte o proibia" (KAFKA, 1922/1998, p. 15). O desjejum era sempre um grande espetáculo, orquestrado nos mínimos detalhes pelo empresário para o deleite da plateia - apenas o artista da fome permanecia insatisfeito, pela interrupção de sua arte. Flagrando-se incompreendido, pois os elogios a ele desferidos Ihe pareciam inócuos, já que não havia alimento algum que o apetecesse - daí a naturalidade de seu ofício.

Essa dinâmica se repetiu por anos a fio, até que "o artista da fome se viu um dia abandonado pela multidão ávida de diversão que preferia afluir a outros espetáculos" (KAFKA, 1922/1998, p. 20). O esperado surge, então, inapelável: com o tempo, esse tipo de espetáculo sai de moda, e esse "mártir digno de compaixão", depois de "ser amado por milhares de pessoas" e não dispondo de outra ocupação vai para um circo: "sendo assim, demitiu o empresário, companheiro de uma carreira incomparável, e se empregou em um grande circo" - embora deixando de ser destaque, não merecendo o centro do picadeiro, mas sim uma jaula longe, vizinha dos estábulos. Passou a ser visto somente de passagem e nos intervalos dos espetáculos, quando os visitantes sobrevoavam os olhos desinteressados sobre os animais ali confinados. No máximo, demorava-se algum homem saudoso contando a seus filhos da época em que fazia sentido esse tipo de arte - e as crianças sequer conseguiam compreender o que significa passar fome.

E o artista da fome, não mais passível de interesse, passa da condição de singular e admirável ritual para mero entretenimento. Sem o brilho de uma plateia atenta e espantada, a sua arte, inscrita em seu próprio corpo, degrada-se - e ele se lembrava das crianças que outrora o olhavam "com assombro, de boca aberta, uma segurança a mão da outra por insegurança, aquele homem pálido, de malha escura, as costelas extremamente salientes, que desdenhava até uma cadeira para ficar sentado sobre a palha espalhada no chão" (KAFKA, 1922/1998, p. 15). 
Do "esplendor aparente" à melancólica invisibilidade, a sua sentença foi lavrada ao não sucumbir ao imperativo da indústria cultural - e insistir em um ofício não mais passível de relevo e alcance popular. "Nada mais podia salvá-lo" (KAFKA, 1922/1998, p. 22). E foi assim que silenciosamente definhou e quedou - morte essa provocada não pela fome, seu horizonte e redenção, mas pela falta erigida pelo fim da sua arte, por não ter encontrado o alimento que o agradasse, como chega a confessar, suas últimas palavras. $O$ excerto abaixo ilustra a sua resistência, justamente por não ter sucumbido às exigências de seu empresário - o de interromper, por exemplo, o jejum - e aos novos tempos, nos quais o seu ofício não mais encontrava público:

Passaram-se ainda muitos dias e até isso chegou ao fim. Certa vez um inspetor notou a jaula e perguntou aos serventes por que deixavam sem uso aquela peça perfeitamente aproveitável com palha apodrecida dentro; ninguém sabia, até que um deles, com a ajuda da tabuleta, se lembrou do artista da fome. Levantaram a palha com ancinhos e encontraram nela o jejuador.

- Você continua jejuando? - perguntou o inspetor. - Afinal quando vai parar?

- Peço desculpas a todos - sussurrou o artista da fome; só o inspetor, que estava com o ouvido colado às grades, o entendia.

- Sem dúvida - disse o inspetor, colocando o dedo na testa, para indicar aos funcionários, com isso, o estado mental do jejuador. - Nós o perdoamos.

- Eu sempre quis que vocês admirassem meu jejum - disse o artista da fome.

- Nós admiramos - retrucou o inspetor. - Por que não haveríamos de admirar?

- Mas não deviam admirar - disse o jejuador.

- Bem, então não admiramos - disse o inspetor. - Por que é que não devemos admirar?

- Porque eu preciso jejuar, não posso evitá-lo - disse o artista da fome.

- Bem se vê - disse o inspetor. - E por que não pode evitá-lo?

- Porque eu - disse o jejuador, levantando um pouco a cabecinha e

falando dentro da orelha do inspetor com os lábios em ponta, como se fosse um beijo, para que nada se perdesse. - Porque eu não pude encontrar o alimento que me agrada. Se eu o tivesse encontrado, pode acreditar, não teria feito nenhum alarde e me empanturrado como você e todo mundo (KAFKA, 1922/1998, p. 23, grifos meus).

O drama vivenciado pelo jejuador alinha-se ao salto historicamente operado entre a arte popular e a chamada indústria cultural, as quais se distinguem radicalmente. Enquanto a primeira assume um caráter espontâneo, internamente nascida e encenada em uma determinada comunidade, a indústria cultural constitui uma manifestação maquinal produzida exteriormente, em escala e sob a égide do capital. Deriva, então, da expansão do capitalismo sobre a cultura, como, de modo inaugural, pensaram Theodor W. Adorno e Max Horkheimer, em 1947, nos fragmentos 
filosóficos reunidos sob o título de Dialética do Esclarecimento. A contraposição entre o debilitado homem e as fascinantes feras do circo confirma como o jejuador era passível de substituição, não exatamente nos termos dos artefatos produzidos pela indústria cultural, mas já inserido em um ambiente que rechaça o gesto ritual em detrimento de recreações imediatas, ligeiras e desproblematizadas.

Não à toa, o conto kafkiano se encerra com olhares ávidos pousados em uma vigorosa pantera, que "nem da liberdade parecia sentir falta", exatamente na jaula em que $\mathrm{o}$ artista da fome findou os seus dias, paulatinamente apodreceu e sumariamente foi varrido junto com as palhas secas que ali restaram. Na jaula em que ocupava, e mal sentiram sua falta, o portentoso felino, para o qual "nada lhe faltava" e "nem da liberdade ela parecia sentir falta":

Mas na jaula puseram uma jovem pantera. Era um alívio sensível até para o sentido mais embotado ver aquela fera dando voltas na jaula tanto tempo vazia. Nada Ihe faltava. $O$ alimento de que gostava, os vigilantes traziam sem pensar muito; nem da liberdade ela parecia sentir falta: aquele corpo nobre, provido até estourar de tudo o que era necessário, dava a impressão de carregar consigo a própria liberdade; ela parecia estar escondida em algum lugar das suas mandíbulas. E a alegria de viver brotava da sua garganta com tamanha intensidade que para os espectadores não era fácil suportá-la. Mas eles se dominavam, apinhavam-se em torno da jaula e não queriam de modo algum sair dali (KAFKA, 1922/1998, p. 23, grifos meus).

Nessa perspectiva da indústria cultural, desdobrando-se a noção trazida por Adorno e Horkheimer, o avanço da lógica de capitalista sobre o domínio da cultura se verte na reificação da arte, das ideias e até mesmo do corpo, cada vez mais regidos pelo imperativo da fruição rápida exigida pela sociedade do consumo e do lucro. Nesse "desencantamento do mundo", os ritos originários e fundadores passam a ser progressivamente desprezados.

O programa do esclarecimento era o desencantamento do mundo. Sua meta era dissolver os mitos e substituir a imaginação pelo saber. [..] 0 mito converte-se em esclarecimento, e a natureza em mera objetividade. 0 preço que os homens pagam pelo aumento de poder é a alienação daquilo sobre o que exercem o poder. $O$ esclarecimento comporta-se com as coisas como o ditador se comporta com os homens. Este conhece-os na medida em que pode fazê-las. É assim que seu em-si torna para-ele. Nessa metamorfose, a essência das coisas revela-se como sempre a mesma, como substrato de dominação. Essa identidade constitui a unidade da natureza. Assim como a unidade do sujeito, ela tampouco constitui um pressuposto da conjuração mágica. Os ritos do xamã dirigiam-se ao vento, à chuva, à serpente lá fora ou ao demônio dentro do doente, não a matérias ou exemplares. [...] Quanto mais a maquinaria do pensamento subjuga o que existe, tanto mais 
cegamente ela se contenta com essa reprodução. (ADORNO; HORKHEIMER, 1947/2006, p.17; $21 ; 34$, grifos meus).

No mundo em que despontava a força industrial massificadora, a arte, espontaneamente surgida no meio popular, é relegada. Verlaine Freitas comenta:

[...] Adorno diz que a cultura de massa como um todo é narcisista, pois ela vende a seus consumidores a satisfação manipulada de se sentirem representados nas telas do cinema e da televisão, nas músicas ou nos vários espetáculos. Todos os heróis da indústria cultural são sempre pensados para refletir algo do que as pessoas já percebem em si mesmas, só que engrandecido pela elaboração dos meios técnicos cada vez mais refinados da indústria da diversão (FREITAS, 2003, p.19.)

Ao tomarmos o ofício do jejuador como uma alegoria da práxis artística e da verdade genuína do artista, o qual não se rende à previsível ordem do entretenimento, tal resistência configura, então, a própria angústia do homem moderno que se debate entre as exigências do capital e a sua expressão individual.

\section{Jesus-Shiva e a crítica à sociedade do consumo}

Por analogia, remeto-me à polêmica exposição Queermuseu - Cartografia da Diferença na América Latina, inaugurada em Porto Alegre em setembro de 2017, reunindo 270 obras de 85 artistas, incluindo nomes do primeiro time da arte nacional, como Lygia Clark, Cândido Portinari, Alfredo Volpi, Adriana Varejão e Leonilson. A mostra foi suspensa em decorrência de contundentes ataques homofóbicos e ostensiva pressão junto ao banco patrocinador por parte de grupos religiosos, coletivos sociais e partidos políticos ideologicamente conservadores. Trata-se de um conjunto de obras relacionadas ao conceito queer - termo que guarda a noção original de "estranho", "excêntrico", "incomum", "bizarro" e que passou a ser alinhado aos sujeitos não heteronormativos e não binários, ou seja, um qualificativo genérico a gays, lésbicas, bissexuais e transgêneros. Nos Estados Unidos, especialmente a partir dos anos 80, a expressão assumiu relevo e ganhou força política e teórica, passando a designar uma atitude transgressiva de pensar e estar no mundo.

Também a kafkiana figura do artista da fome pode ser conjugada à pintura do gaúcho Fernando Baril pela via do estranhamento e do desconforto - estendida a um público, em geral, pouco afeito a provocações nada aprazíveis e que desestabilizam 
um olhar condicionado a representações consagradas. Composta em 1996, a tela Cruzando Jesus com o Deus Shiva (Figura 1) constituiu, então, um dos argumentos para o encerramento da exposição, sendo considerada "profana", "desnecessária", "escandalosa", como é possível atestar em uma rápida pesquisa nos jornais da época. Em sua obra, a tradicional imagem de Cristo crucificado - e que assim habita o imaginário ocidental há séculos - é subvertida, pois adornada por catorze braços desconexos portando objetos variados da cultura de massa, bem como três pares de pés, que se somam a um Jesus despojadamente calçado com tênis esportivos, chinelos havaianas e botas de salto.

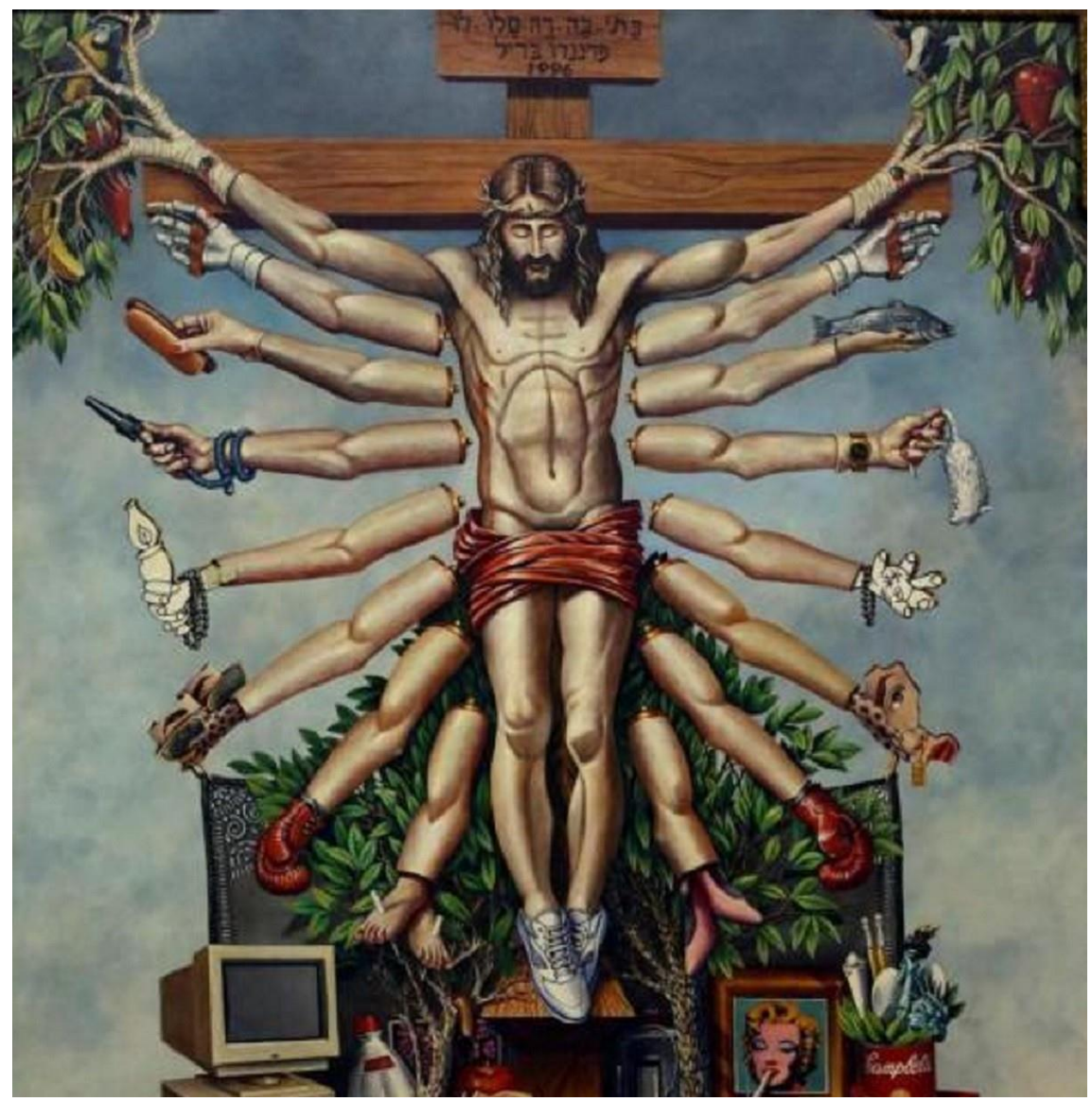

Figura 1 - Cruzando Jesus com o Deus Shiva. Fernando Baril.

O artista plástico desestabiliza a matriz cristã ao engastar, em seu singularíssimo Cristo, elementos da mitologia hinduísta, evocando, como o próprio título da pintura indica, Shiva, deus a um só tempo da destruição e da regeneração, e ainda, plasticamente, a deusa Durga (esposa de Shiva), igualmente guerreira e dotada de oito braços, carregando armas e assumindo mudras (gestos feitos com os dedos das mãos que indicam uma postura de deferência sagrada, significando selo, senha, chave), encarnando, também, o feminino e a energia criativa. 
Em seus múltiplos braços em arco, o Jesus moderno do artista gaúcho também se inscreve na fronteira grotesco-sublime, subvertendo (e até mesmo rebaixando) a dimensão sagrada atribuída ao deus de Jerusalém, em sua face histórica e humana. Interessante notar que, diferentemente da representação hinduísta, no quadro de Fernando Baril os braços de Jesus estão apartados do corpo, sugerindo, assim, uma cisão com a sacralidade da figura original, como se fossem próteses mecânicas ou membros de bonecos, sustentando ainda objetos estranhos tanto à religião cristã quanto à oriental, com exceção do peixe, símbolo do cristianismo. Os demais elementos são ícones da sociedade industrial: um computador, luvas de boxe, cachorro quente, além dos pés de Cristo calçados com tênis. Sobre a mesa, outros signos do perecível mundo contemporâneo: uma imagem de Marilyn Monroe, uma garrafa pet de Coca Cola, uma lata retrô a la Andy Warhol do movimento da pop art. Já o rato morto ilustra a decadência dos espaços urbanos e seus inevitáveis dejetos e esgotos. Em uma análise da obra, na perspectiva bakhtiniana acerca do grotesco, João Vianney Cavalcanti Nuto assim dispõe:

\begin{abstract}
Uma das mãos segura um rato morto. Embora não seja um produto industrializado como os outros, o rato, como animal nocivo que prolifera nas grandes cidades, pode ser associado à sujeira aos dejetos, aos esgotos, que essa mesma sociedade pretende esconder (pelo menos nos espaços privilegiados) e que, no entanto, permanecem. Esta associação complementa-se pela presença do rato vivo na mesa que sustem a imagem de Cristo. O grotesco da imagem acentua-se nos braços inferiores, terminados não por mãos, mas por pés e (aparentemente) pênis (NUTO, 2017, p. 149, grifo meu).
\end{abstract}

Ao recorrer a esse cruzamento o que pretendeu o pintor? Ressignificar Jesus, ampliando o seu alcance sagrado junto ao Oriente, blasfemar o ícone máximo do cristianismo (como assim compreenderam os conservadores), ou empreender uma crítica incisiva à apropriação moderna de Jesus e seus apelos voltados ao consumo estéril e imediatista? Não seria um modo de denunciar, desse modo, o kitsch religioso e tantos souvenires comercializados a esmo e que se perderam do seu significado irradiador original?

Dissociando-se radicalmente do cânone, Fernando Baril se vale do grotesco, estilo (re)valorizado pelos românticos, especialmente Schlegel - "a destruição da ordem habitual do mundo na livre excentricidade das imagens" (SCHLEGEL apud ECO, 2014, p. 280) e Victor Hugo, em seu célebre ensaio no qual o define como o 
modo de realçar o sublime, atuando em contraste (HUGO, 2012, p. 33). Essas representações perturbadoras - tanto as associadas ao cômico quanto ao "baixo material e corporal" a partir das formulações Mikhail Bakhtin, em sua análise da obra de Rabelais (BAKHTIN, 1996), - vêm desdobrando-se até a atualidade, legando as provocações mais diversas, a exemplo das vanguardas históricas e da arte contemporânea. Ainda de acordo com Nuto, ao salientar a obtusidade da recepção crítica da obra por parte dos grupos conservadores:

\begin{abstract}
O tratamento da imagem é profano, no sentido de dessacralizador, como seria qualquer tratamento que não envolvesse a pura adoração, incluindo qualquer estudo, ou mesmo a reprodução de imagens de Cristo, da Virgem Maria, ou de qualquer imagem sacra em camisetas ou objetos de souvenir (o kitsch religioso) que certos cristãos ostentam orgulhosamente, sem ver nisso qualquer traço de ofensa. Tão empenhados em denunciar a blasfêmia, os grupos conservadores não leram (mesmo porque, para ler, é preciso contemplar) a crítica mordaz à sociedade de consumo e a adaptação do sentimento religioso ao seu ethos. É esse tipo de adaptação que preside as diversas teologias da prosperidade, as quais associam a felicidade ao consumo, não tendo o pudor de ocultar seu interesse comercial ao exporem à venda os mais variados objetos "milagrosos" - capazes de melhorar ou mesmo salvar a vida do fiel -, sejam esses objetos supostas relíquias (como lascas da cruz de Cristo), ou objetos industriais, como vassouras, sabonetes de detergentes "ungidos". (NUTO, 2017, p. 149, grifo meu).
\end{abstract}

O próprio Fernando Baril considera textualmente que o caso não passa de "conservadorismo enrustido". Suas palavras, em entrevista a Lucas Simões: "É uma crítica à Igreja, de como a instituição nos empurra as coisas, principalmente o consumo do Ocidente. $E$ isso afeta o mundo inteiro. Eu realmente não sei onde as coisas vão parar. Talvez nem na ditadura tivemos uma patrulha tão incisiva" 2 (SIMÕES, 2017, s.p.). Na mesma reportagem: "Para cristãos, a obra, mesmo pintada há quase duas décadas, se enquadra no artigo 208 do Código Penal, que atesta crime "vilipendiar publicamente ato ou objeto de culto religioso" (2017, s. p.).

\title{
Considerações finais
}

O Cristo ressignificado na cultura pop - e conjugado ainda a outra matriz religiosa - não deixa de ressoar o que Francisco de Goya dispôs em sua gravura intitulada "O sono da razão produz monstros", um autorretrato no qual

\footnotetext{
${ }^{2}$ Disponível em: https://www.obeltrano.com.br/portfolio/queermuseu-quando-estupidez-silencia-arte/ Acesso em: 3 mar. 2021.
} 
melancolicamente se curva sobre uma mesa, em um estado que alterna aflitiva vigília e incontido adormecimento. Por trás do pintor, morcegos e corujas, criaturas noturnas que personificam seus medos, fantasmas e obsessões. Já o gato, a seus pés, de olhos acesos e abertos, parece assumir uma postura de assumida vigilância, de não esquiva da realidade que o circunda. Despertar a Espanha do sono da ignorância, mesmo sendo pintor da corte, constituiu um dos seus lemes como artista e homem político, que não declinou da denúncia da hipocrisia, da vulgaridade e da pobreza de espírito, além da crítica veemente ao horror da Inquisição e à opressão sanguinolenta das tropas napoleônicas após a revolução.

Poucos escritores personificam de modo tão contundente a angústia do homem moderno como Franz Kafka, que, somando-se ao desajuste social, desolação existencial e radicalizado estranhamento ante seus pares e o próprio tempo, enfrentou a dupla marginalização de ter sido, da escola primária à universidade - na qual estudou Direito -, educado na língua germânica na cidade de Praga, na antiga Boêmia, não deixando de ser visto como um alemão entre os tchecos e um judeu (subraça) em meio aos austríacos e alemães. Parte da fortuna crítica kafkiana reconhece - para além do autor metafísico ou solipsista, e até mesmo existencialista, antecipando Camus e Sartre - que os seus postulados ficcionais consubstanciam expressivas críticas sociais. Steiner lembra que "sua visão da esperança radical era sombria; por trás da marcha da revolução proletária, viu o inevitável proveito do tirano e do demagogo" (STEINER, 1988, p. 158), bem como o fato de ter cursado Direito lhe dera "uma visão nítida das relações de classes e das realidades econômicas" (p. 158). Modesto Carone nos lembra ainda que:

\footnotetext{
Mas existe também um tipo de "passagem" de sentido que, por ser refinada (e não trivial), não é percebida como tal. Foi dito atrás que "a escrita de Kafka é fina e flexível como uma folha de aço". A comparação só seria um enigma se não fosse óbvia. $O$ próprio Kafka queria que sua literatura fizesse doer como um estilete fincado no corpo. Ou seja, não é sobre a metáfora em si que o escritor se interessa, mas sobre o efeito artístico (e de conhecimento) que faz dela aquilo que é. Em realidade, os textos kafkianos podem ser lidos como uma cadeia de imagens (CARONE apud KAFKA, 2011, p. 7, grifo meu).
}

Nessa perspectiva, as criações ficcionais, que ampliam agudamente o real, podem ser compreendidas na chave transformadora defendida por Antonio Candido, a ser incorporada como "instrumento poderoso de instrução e educação": 
Chamarei de literatura, da maneira mais ampla possível, todas as criações de toque poético, ficcional ou dramático em todos os níveis de uma sociedade, em todos os tipos de cultura, desde o que chamamos folclore, lenda, até as formas mais complexas e difíceis da produção escrita das grandes civilizações. Vista deste modo a literatura aparece claramente como manifestação universal de todos os homens em todos os tempos. Não há povo e não há homem que possa viver sem ela, isto é, sem a possibilidade de entrar em contato com alguma espécie de fabulação. Assim como todos sonham todas as noites, ninguém é capaz de passar as vinte e quatro horas do dia sem alguns momentos de entrega ao universo fabulado. (...) Cada sociedade cria as suas manifestações ficcionais, poéticas e dramáticas de acordo com os seus impulsos, as suas crenças, os seus sentimentos, as suas normas, a fim de fortalecer em cada um a presença e atuação deles. Por isso é que nas nossas sociedades a literatura tem sido um instrumento poderoso de instrução e educação, entrando nos currículos, sendo proposta a cada um como equipamento intelectual e afetivo (CANDIDO, 1988/2011, p. 176-177, grifos meus).

Por meio desses anti-heróis contemporâneos fraturados, por meio do nosso olhar de espanto e desconcerto, o mundo é relido. Pois tanto o Cristo criticamente ressignificado na cultura pop quanto o jejuador de Kafka, encerrado em sua inegociável verdade como artista, o qual não sucumbe às exigências facilitadoras do entretenimento, configuram polos de emblemática resistência ao mundo imediatista e reificado do consumo estéril e voraz, carreando a angústia do homem moderno dos séculos 20 e 21, em renovável contradição entre se assumir como sujeito político e conviver com o progresso tecnológico e a exclusão social.

\section{Referências bibliográficas}

ADORNO, Theodor; HORKHEIMER, Max. Dialética do Esclarecimento. Tradução de Guido Antonio de Almeida. Rio de Janeiro: Zahar, 2006.

BAKHTIN, M. A cultura popular na Idade Média e no Renascimento: o contexto de François Rabelais. São Paulo: Hucitec; Brasília: EdUnb, 1996.

BOSI, Alfredo. Literatura e Resistência. São Paulo: Companhia das Letras, 2002.

CANDIDO, Antonio. Vários Escritos. Rio de Janeiro: Ouro sobre Azul, 2011, p. 171193. (Texto originalmente publicado em 1988).

CARONE, Modesto. "Um perfil rápido, mas necessário". In: Franz Kafka - Essencial. Tradução de Modesto Carone. São Paulo: Penguim Companhia, 2011, p. 4-9. 
. "Histórias de um mestre no fim da vida". In: Um artista da fome /

A construção. São Paulo: Companhia das Letras, 1998, p. 73-75.

ECO, Umberto. História da feiura. Tradução de Eliana Aguiar. Rio de Janeiro: Record, 2014.

FREITAS, Verlaine. Adorno e a arte contemporânea. Rio de Janeiro: Zahar, 2003.

HUGO, Victor. Do grotesco e do sublime. Tradução de Célia Berrettini. São Paulo: Perspectiva, 2012.

KAFKA, Franz. Um artista da fome / A construção. São Paulo: Companhia das Letras, 1998 (“Um artista da fome” foi originalmente publicado em 1922).

NUTO, João Vianney Cavalcanti. “Corpo grotesco, corpo político”. In: ENCONTRO DE ESTUDOS BAKHTINIANOS (EEBA): Das resistências à escatologia política: risos, corpos e narrativas enunciando uma ciência outra. 4., 2017, São Carlos. Anais [...]. São Carlos: Pedro \& João Editores, 2017. p.144-150.

ROSENFELD, Anatol. Letras e Leituras. São Paulo: Perspectiva, 1999.

SIMÕES, Lucas. Queermuseu: quando a estupidez silencia a arte. O Beltrano, [Online], Disponível em: https://www.obeltrano.com.br/portfolio/queermuseu-quandoestupidez-silencia-arte/. Acesso em: 2 abr. 2021.

STEINER, George. Linguagem e Silêncio. Tradução de Gilda Stuart e Felipe Rajabally. São Paulo: Companhia das Letras, 1988. 